\title{
KARET LEMBARAN YANG TERBUAT DARI CAMPURAN SERBUK BAN BEKAS DAN KARET ALAM YANG DISETARAKAN DENGAN SIR-20 UNTUK PEMBUATAN SOL SEPATU OLAH RAGA
}

\author{
Ojakma Tumanggor $S^{1}$, Anwar Dharma $S S^{2}$, Eddy Marlianto $S^{3}$ \\ ${ }^{1}$ Mahasiswa Universitas Sumatera Utara \\ ${ }^{2,3}$ Program Magister Ilmu Fisika Fakultas MIPA Universitas Sumatera Utara \\ ${ }^{2,3}$ Departemen Fisika, Fakultas MIPA Universitas Sumatera Utara \\ ${ }^{1}$ Email : ojakmatumanggor@yahoo.co.id Ino hp 081375075942
}

\begin{abstract}
The study of waste tires powder processing as a filler on making shoe sole has been done. On the research, it has been found the vulcanizate technical on natural rubber of shoe sole by using waste tires powder and was compound to the tecto the technical specification of shoe sole according to Indonesia Natural Standard. The process of making waste tires powder triller 60 mesh particle size has been done by steps of procces, producing of particle size, washing, drying and screening. The vulcanizate of natural rubber shoe sole wich contained waste tires powder and using press molding technical at 1800 for 4,50 minutes. The result of the research showed that the vulcanizate of shoe sole natural rubber containing waste tires powder triller 60 mesh could be used to manufacturing sport shoe sole because its process accoording to Indonesia National Standard 06-1844 99 Ed 1.2
\end{abstract}

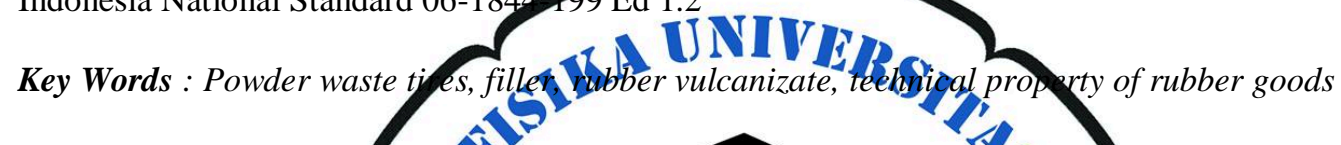

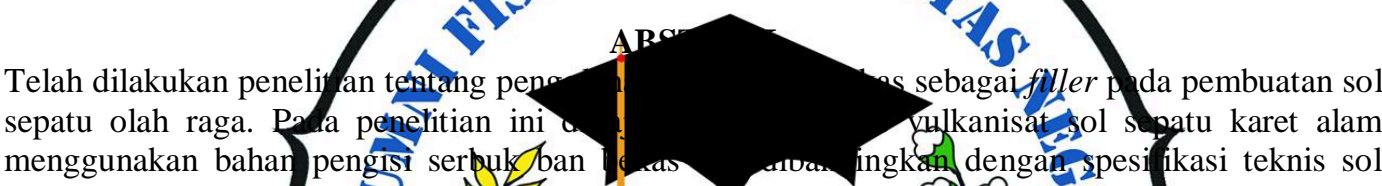
sepatu berdasarkan Standar Na Indonesia. Pembuatan berathengis se puk ban bekas

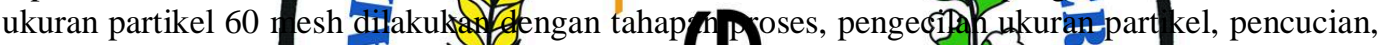

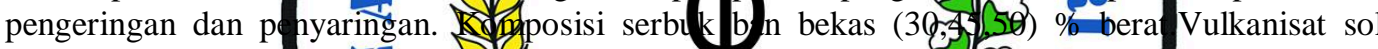
sepatu karet alam b rbaham pen serbuk ban be as dan menggun tehnik c tak tekan pada

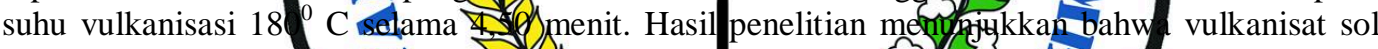

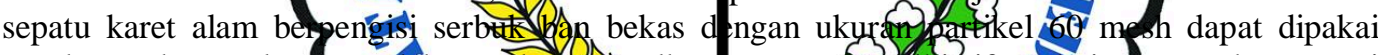

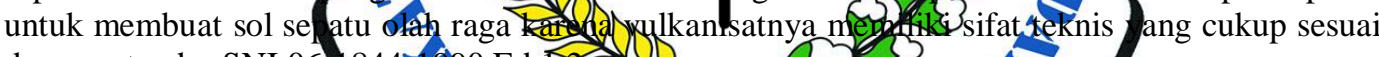
dengan standar SNI 06

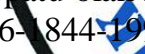
Ed T

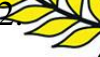

\section{Kata Kunci : Serbuk Ban Bkas, Bahan Pengisi,Vulkanisat Karet, Sifat tek us barang jadi karet.}

\section{Pendahuluan}

Di Indonesia karet merupakan saran satu

hasil pertanian terkemuka karena banyak menunjang perekonomian negara, salah satu kegunaannya adalah untuk pembuatan ban pada kendaraan. Dengan meningkatnya hasil karet indonesia,maka meningkat pula industri ban yang bahan utamanya adalah karet. Sejalan dengan itu keberadaan ban-ban bekas yang sudah tidak terpakai juga semakin banyak yang tentu saja menjadi masalah dalam pencemaran lingkungan. Masalah ini semakin besar dikarenakan ban bekas tidak dapat terurai dengan mudah bila dibiarkan begitu saja. ( Shulan Zhao, Lili Wang and Lian Duo 2009).

Penggunaan ban-ban bekas yang berwawasan lingkungan banyak mendapat perhatian. Sekitar enam ribu ton ban bekas dihasilkan setiap tahun di Eropa, Amerika dan Jepang. Hal ini akan terus meningkat sejalan dengan meningkatnya industri otomotif dunia. Upaya pemusnahan dengan cara pembakaran yang biasa dilakukan ternyata menghasilkan dampak polusi var berbahaya karena berpengaruh buruk patra kesehatan manusia ( M. Juma, 2006 ). Jika dibuang begitu saja, ban bekas tentunya akan mencemari lingkungan sekitarnya mengingat ban bekas tidak dapat terurai dengan mudah secara biologis ( Baharuddin, 2010 ).

Pengolahan ban bekas menjadi serbuk ban bekas adalah salah satu teknik menarik untuk pemanfaatan ban-ban bekas, oleh karena itu, diperlukan usaha untuk mengubah limbah ban bekas menjadi sesuatu yang lebih berguna, salah satunya memanfaatkan serbuk ban bekas menjadi bahan isian karet lembaran untuk tujuan pembuatan bahan sol sepatu.

Erna Frida (2012) telah melakukan penelitian melihat Pengaruh Ukuran dan komposisi serbuk ban bekas sebagai Filler dengan Kompatibeliser PP-g-MA pada campuran Polipropilena dan Kompon SIR-20 terhadap Sifat Mekanik dan Termal. Polipropilena yang diperkuat dengan serbuk ban bekas dengan ukuran 60 mesh 1 
mm, dan komposisi serbuk ban bekas $(30,40$, dan 50) \%berat. Sifat mekanik yang diamati adalah Kekuatan tarik, Perpanjangan putus, Modulus Young, Kekuatan sobek, dan Kekuatan impact.

Nurdin Bukit (2011) telah melakukan penelitian melihat pengaruh Penambahan bahan pengisi ukuran partikel pada komposit polipropilena yang berisi serbuk ban bekas,pada penelitian itu, ban bekas dibuat komposit dengan mencampurkan PP/serbuk ban bekas/kompon SIR20 dengan komposisi dan ukuran yang bervariasi, serbuk ban bekas $(30 \%, 40 \%, 50 \%$ berat) dan kompon SIR-20 (40\%,30\%,20\% berat) serta ukuran ban bekas (60 mesh dan $1 \mathrm{~mm}$ ) dan diuji sifat mekanik (kekuatan tarik, perpanjangan saat putus,modulus young).

\section{Metodologi Penelitian \\ Bahan}

\section{Tabel 2.1. Formula Kompon Karet drigan variasi Frail dan Pembahasan} bahan pengisi serbuk ban bekas antuk pembuğtẩ I VT Hasil Penelitian vulkanisat sol sepatu \begin{tabular}{|l|l|l|l|l|}
\hline \multicolumn{1}{|c|}{ Bahan } & Karet Alam & Serbuk Ban Bekas
\end{tabular} tetap, Alat uji bobot jenis (Densi meter), Alat uji ketahanan kikis,Ayakan, Rheo Meter, Jangka sorong, Pisau/cutter, Thicnes Tester, Gelas beker, Pinset, Neraca analitik.

\section{Pembuatan Sampel}

Adapun langkah-langkah yang dilakukan dalam pembuatan sampel pada penelitian ini adalah sebagai berikut :

1. Pembekuan Lateks

Lateks kebun cair dimasukkan dalam bak penggumpal dibubuhi dengan asam format $5 \%$ selama 24 jam
2. Peremahan.

Koagulan dari bak pembekuan dimasukkan kedalam mesin pisau berputar (rotari cutter)

3. Di Oven selama satu jam dalam suhu 100 ${ }^{0} \mathrm{C}$ terbentuk karet lembaran ( karet Kering)

4. Kemudian dilakukan pencampuran dengan serbuk ban bekas sesuai dengan perbandingan yang sudah ditentunkan ditambah bahan kimia untuk proses pembuatan kompon, kegiatan tersebut akan menghasilkan lembaran-lembaran karet yang kita inginkan.

5. Lakukan pengujian

6. Lembaran Karet ini kemudian divulkanisasi

7. Lakukan Pengujian 


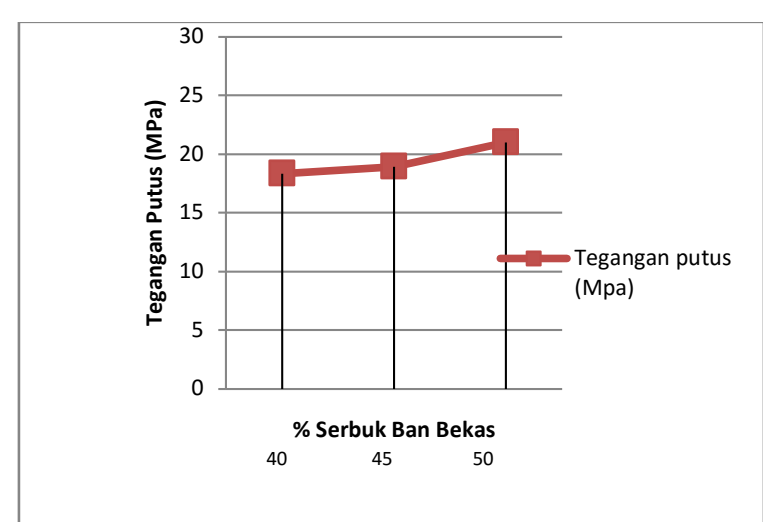

Gambar 3.1. Grafik Hasil Uji Tegangan

Putus

\section{Perpanjangan Putus}

Perpanjangan putus menunjukkan kemampuan vulkanisat meregang apabila ditarik sampai putus. Nilai rata-rata perpanjangan putus vulkanisat yang diperoleh adalah : vulkan 430, vulkanisat B 400 dan vulkanisat C 20. Hasil uji perpanjangan putus karet alam d sajikan pada Gambar 3.2. Grafik ini menu jukkar bahwa semakin besar kadar serbuk ban naka semåkin sulit untuk ditarik karena bahan to sebut mákin keras Semakin keras bahan vulka isat yang dih
maka sifat elastis bahan kary semakin berkurang.

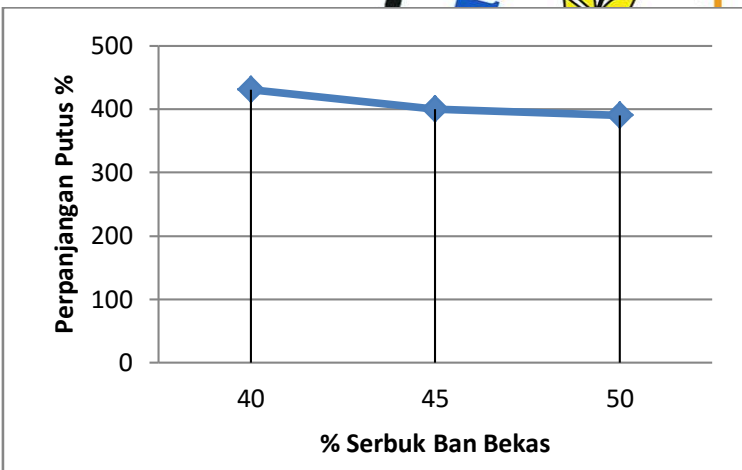

Gambar 3.2 Grafik Hasil Uji

Perpanjangan Putus

Nilai perpanjangan putus akan lebih rendah karena sifat bahan pengisi yang dapat meningkatkan kekerasan, ketahanan sobek, ketahanan kikis, dan tegangan putus pada produk karetnya tetapi akan menurunkan nilai perpanjangan putusnya. Hal ini menunjukkan bahwa sifat perpanjangan putus karet alam pada vulkanisat dipengaruhi oleh jenis bahan bakunya dan jika diaplikasikan pada barang jadi karet, perpanjangan putus barang jadi karet juga dipengaruhi oleh jenis bahan bakunya.

\section{Kekerasan}

Nilai kekerasan karet karet alam untuk ketiga vulkanisat ( vulkanisat A,B dan C) berturutturut adalah 64, 64,5 dan 65. Hasil uji kekerasan vulkanisat karet alam disajikan pada Gambar 3.3.

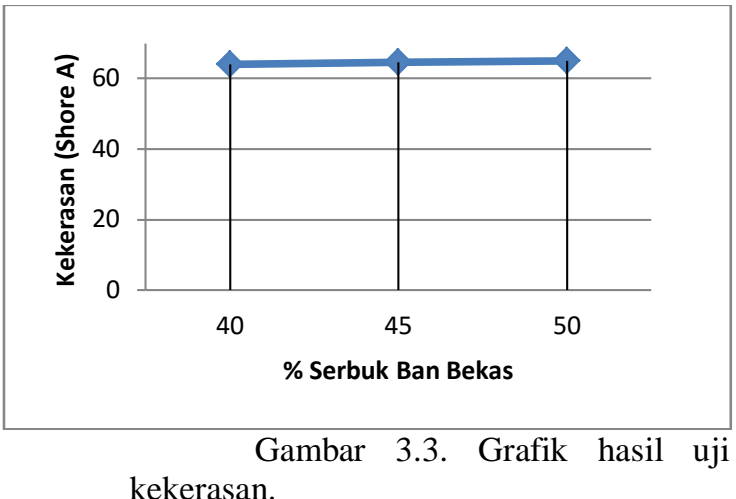

Dari grafik diatas terlihat bahwa semakin banyak kadar serbuk ban bekas maka hasil vulkanisatnukya semakin tinggi, hal ini menunjukkan bahwa semakin banyak kadar serbuk ban bekas maka hasil vulkanisatnya semakin keras. Hasil pengujian menunjukkan bahwa dalam pembuatan kompon karentak terlihat perbedaan yang antara kompon Y -yang bahan pengisi yang banyak dan yang sedikit. Hal inifdisebalk karena sifat lateks baik yaitu bobot mótekutydan ju plah protein rendah.

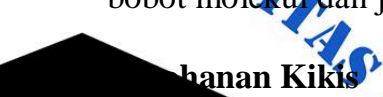

hanan Kikis ${ }^{2}$ tahananta kiks merupakan nilai spar) karet-bertahr terhadap gesekan dengar beneg lain. Nylai ketahanan kikis adalah volume karewyang tapat likikis oleh pengikis Dehingga senal impendäh ni ai ketahanan kikisnya maka semakin) bajk sifat kar t tersebut. Nilai ratarata ketahapan kikis latng liperoleh dalam hasil

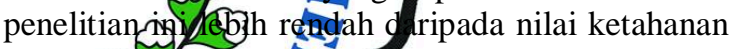
kikis tary Oppesifikasi y ng ditetapkan sebagai acyon, bani menumukk n bahwa ketahanan kikis

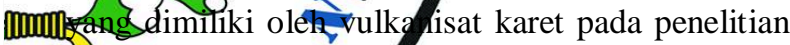
in adalah baik untuk ketiga vulkanisat. Hasil uji I Katahanan kikis vy/Kanisat karet alam disajikan

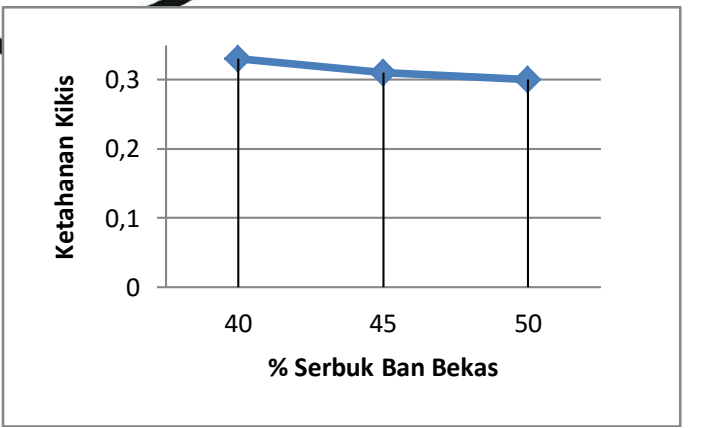

Gambar 3.4. Grafik hasil uji ketahanan kikis

\section{KESIMPULAN}

Hasil penelitian menunjukkan bahwa Semakin besar \% kadar serbuk ban bekas diberikan kepada lateks kebun sebagai filler untuk vulkanisat maka nilai tegangan putus,kekerasan, dan ketahanan kikis semakin besar. Berdasarkan hasil yang diperoleh pada penelitian ini maka serbuk ban bekas dapat digunakan sebagai bahan pengisi untuk 
membuat sol karet sepatu olahraga karena vulkanisatnya memiliki sifat teknis yang cukup sesuai dengan standar SNI 06-1844-1990 Ed 1.2

\section{DAFTAR PUSTAKA}

Anonim,2009,Pengolahan bahan olah karet rakyat (Bokar). http://www.antakowisena.com pengolahan-bahan-olahan-karet-rakyatbokar.html.diakses pada tanggal 16 Desember 2011

Anonim,2010,BahanOlah Karet.http://www.teknoperta.com/doc/2010/ketentuan-bahanolah-karet.html.diakses pada tanggal 16 Desember 2011

Ardiansyah, M.K., 2008,Pengaruh Bentuk Potongan Ban Bekas Jenis Biasa Terhadap Kuat Tarik Belah, Kuat Tekan Dan Kuat Lentur Beton Normal Tugas Akhir Jurusan Teknik Fakultass is dan Teknik Sipil UNSOED, Purwokerto Bukit, Nurdin 2011. "Pen,olahan Zeolit Alam properties of thermoplastic Elastomers Sebagai Bahan Pengisi Nano Komposit Polipropilena Dengan Komp tibeliser Anhidri Baharuddin,2010,Pe buatan Elastome Dan Poli

Carl Thodesen, Mairkhania characteristic orecrumb ind of modifie (CRM) binde viseosity Building Matrials 23
Construction and Building Materials ,www.elsevier.com/ locate/conbuildmat.

Frida, Erna, 2012, "Pengaruh Ukuran dan komposisi serbuk ban bekas sebagai Filler dengan Kompatibeliser PP-g-MA pada campuran Polipropilena dan Kompon SIR-20”. Medan

Setyowati Penny,2004, "Petunjuk Praktikum Teknologi Pembuatan Barang Karet dan Plastik",Balai Besar Kulit Karet dan Plastik: Yogyakarta

Shulan Zhao,LiliWang and Lian Duo , 2009 ," Effects of Waste Crumb Rubber on Medium Characters And Growth of Lolium Perenne L.Pak.J.Bot.41(6):2893-
2900
Zhang ,2009,"Characterization of the
properties of thermoplastic Elastomers "conta ing waste rubber tire powder"
YContent lists available at ScienceDirect, Waste Ma agement journal homepage: wwy.elsen ar.com/locate/wasman

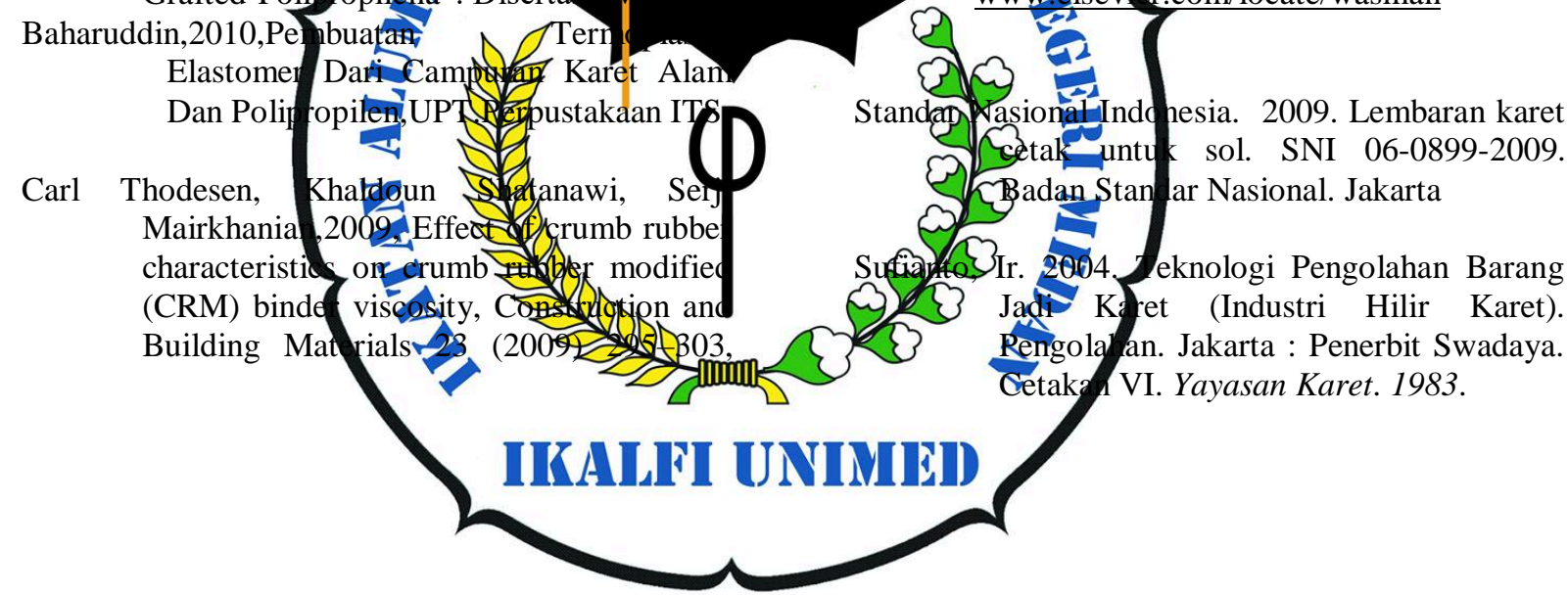

